\title{
PERILAKU POLITIK PEMILIH PEMULA DALAM PELAKSANAAN PEMILIHAN PRESIDEN 2014 DI DESA KANAUNGAN KECAMATAN LABAKKANG KABUPATEN PANGKEP

\author{
Raoda Nur ${ }^{1}$, Ahmad Taufik ${ }^{1}$, Muhammad Tahir ${ }^{2}$ \\ Program Studi Ilmu Pemerintahan Fakultas Ilmu Ssosial dan Ilmu Politik \\ Universitas Muhammadiyah Makassar \\ Jl Sultan Alauddin No 259 Makassar 90221 \\ Telp. 0411-866972 ext. 107. Fax. 0411-8655888 \\ raoda nur@yahoo.com ahmadtaufik@unismuh.ac.id \\ 2 Program Studi Ilmu Adminitrasi Negara Fakultas Ilmu Sosial dan Ilmu Politik \\ Universitas Muhammadiyah Makassar \\ Jl Sultan Alauddin No 259 Makassar 90221 \\ Telp. 0411-866972 ext. 107. Fax. 0411-8655888 \\ muh.tahir@gmail.com
}

\begin{abstract}
The purpose of this study to determine the political behavior of voters in the election of the president and vice president in 2014 and to determine the factors influencing the political behavior of voters in the election of President and Vice President in the village of the District Kanaungan Labakkang Pangkep. This type of research is descriptive qualitative and types of case studies with the number of informants 10 people consisting of 1 Village Head, 1 KPPS, 3 KPPS, and 5-time voters. Data on the political behavior of voters gathered using instruments such as observation, interviews and documentation. The data were analyzed through a phase of data reduction, data presentation and conclusion. The results showed that voters in the vote in the election of the president and vice president are still lacking because of their awareness of the importance in conducting the elections, following the selection of the parents was the main reason in choosing, awe held on the candidate to be the reason in choosing and irrational the use of voting rights held.
\end{abstract}

Keywords: Political Behavior, Voters starters, the Presidential Election

\begin{abstract}
ABSTRAK
Tujuan penelitian ini untuk mengetahui perilaku politik pemilih pemula dalam pelaksanaan pemilihan Presiden dan wakil Presiden 2014 serta untuk mengetahui faktor-faktor yang mempengaruhi perilaku politik pemilih pemula dalam pelaksanaan pemilihan Presiden dan Wakil Presiden Di Desa Kanaungan Kecamatan Labakkang Kabupaten Pangkep. Jenis penelitian adalah deskriftif kualitatif dan tipe penelitian studi kasus dengan jumlah informan 10 orang terdiri dari 1 orang Kepala Desa, 1 orang anggota KPPS, 3 orang anggota KPPS, dan 5 orang pemilih pemula. Data perilaku politik pemilih pemula di kumpul dengan menggunakan instrumen berupa observasi, wawancara dan dokumentasi. Data tersebut dianalisis melalui tahap reduksi data, penyajian data dan penarikan kesimpulan. Hasil penelitian menunjukan bahwa pemilih pemula dalam menggunakan hak pilihnya dalam pemilihan presiden dan wakil presiden masih kurang karena kesadaran mereka akan pentingnya dalam melakukan pemilihan, mengikuti pilihan orang tua menjadi alasan utama dalam memilih, rasa kagum yang dimiliki pada kandidat menjadi alasan dalam memilih dan tidak rasional dalam menggunakan hak suara yang dimiliki.
\end{abstract}

Kata kunci: Perilaku Politik, Pemilih Pemula, Pemilihan Presiden. 


\section{A. PENDAHULUAN}

Pemilu merupakan salah satu pelaksanaan kedaulatan rakyat yang berdasarkan pada demokrasi perwakilan. Dengan demikian, pemilu dapat diartikan sebagai mekanisme penyeleksian dan penyerahan kedaulatan kepada orang atau partai yang di percayai. Orang atau partai yang di percayai, kemudian menguasai pemerintahan sehingga melalui pemilu diharapkan dapat diciptakan pemerintahan yang representatif (refresentative goverment). Selain itu, pemilu sangat sejalan dengan semangat demokrasi secara subtansi atau "demokrasi subtansial" yakni demokrasi dalam pengertian pemerintahan yang di selenggarakan dari rakyat, oleh rakyat, dan untuk rakyat. Artinya, rakyatlah yang memegang kekuasaan tertinggi (kedaulatan).

Pemilihan umum merupakan persyaratan minimum Negara demokrasi. Suatu sistem demokrasi dapat di katakan sudah berjalan ketika terpenuhi beberapa karakteristik, seperti pemilihan umum yang fair dan periodik, pertanggungjawaban Negara di depan rakyat, dan adanya jaminan kebebasan berekspresi dan berorganisasi.

Perilaku politik adalah kegiatan yang berkenaan dengan proses pembuatan dan pelaksanaan keputusan politik yang melakukan kegiatan politik tersebut adalah pemerintah dan masyarakat. Kegiatan yang dilakukan itu pada dasarnya di bagi dalam dua bagian yakni fungsi-fungsi pemerintahan yang di pegang oleh Pemerintah dan fungsi-fungsi politik yang di pegang oleh masyarakat. Namun fungsi Pemerintah, maupun fungsi politik, biasanya dilaksanakan oleh struktur tersendiri, yaitu supra struktur politik bagi fungsi-fungsi politik pemerintahan dan infra struktur politik bagi fungsi-fungsi politik masyarakat.

Partisipasi politik di Indonesia membawa tuntutan yang besar kepada perubahan sistem dan kehidupan masyarakat di Indonesia. Partisipasi politik sebagai hal yang penting dalam perkembangan kehidupan bangsa dan Negara. Pertumbuhan partisipasi politik memerlukan tata nilai yang operasional (dimanifestasikan dalam bentuk perilaku nyata) yang menerima dan menghargai persamaan, keterbukaan dan perbedaan pendapat sehingga terjadi kesinambungan antara masyarakat dan pemerintah.

Kesadaran politik warga Negara menjadi faktor determinan dalam perilaku politik masyarakat, artinya sebagai hal yang berhubungan pengetahuan dan kesadaran akan hak dan kewajiban yang berkaitan dengan lingkungan masyarakat dan kegiatan politik menjadi ukuran kadar seseorang terlibat dalam proses perilaku politik. Pengalaman pemilihan umum yang berlangsung dalam beberapa dekade menunjukan banyaknya para pemilih yang tidak memberikan suaranya. Sebagai fenomena penggambaran di atas apabila seseorang memiliki kesadaran politik dan kepercayaan kepada pemerintah tinggi maka perilaku politik cenderung aktif, sedangkan apabila kesadaran dan kepercayaan sangat kecil maka perilaku politik menjadi pasif dan apatis.

Pemilihan umum sebagai sarana demokrasi yang telah digunakan oleh sebagian besar dunia termasuk di Indonesia, yang memiliki masyarakat yang heterogen. Melalui pemilihan umum maka memungkinkan semua pihak dapat terakomodasi terhadap apa yang sebenarnya mereka inginkan dan citacitakan sehingga menuju kepada kehidupan yang lebih baik. Masyarakat merupakan komponen penentu berhasil atau tidaknya pelaksanaan pemilu. Karena pada dasarnya kekuatan pemilihan masyarakatlah yang dapat menentukan nasib bangsa dan Negara kedepannya.

Sesuai kategori politik kaum remaja dimasukan dalam pemilih pemula, mereka adalah kelompok yang baru pertama kali menggunakan hak pilih, dengan hak pilih 
itu kaum remaja yang berusia 17 tahun atau sudah menikah ini akan mempunyai tanggung jawab kewargaNegaraan yang sama dengan kaum dewasa yang lain. Para pemilih pemula yang kebanyakan dari siswa siswi sekolah menengah atas serta mahasiswa / mahasiswi yang baru memasuki usia hak pilih pastilah belum memiliki jangkauan politik yang luas untuk menentukan ke mana mereka harus memilih. Sehingga, terkadang apa yang mereka pilih tidak sesuai dengan yang diharapkan. Alasan ini pula yang menyebabkan pemilih pemula sangat rawan untuk digarap dan didekati dengan pendekatan materi.

Menurut pasal 1 ayat (22) UU No 10 Tahun 2008, pemilih adalah warga Negara Indonesia yang telah genap berumur 17 ( tujuh belas) tahun atau lebih atau sudah/pernah kawin, kemudian pasal 19 ayat (1 dan 2) UU No 10 Tahun 2008 menerangkan bahwa pemilih yang mempunyai hak memilih adalah warga Negara Indonesia yang di daftar oleh penyelenggara Pemilu dalam daftar pemilih dan pada hari pemungutan suara telah genap berumur 17 (tujuh belas) tahun atau lebih atau sudah/pernah kawin.

Pemilih pemula sekarang ini masih banyak tidak menggunakan hak pilihnya dalam pemilihan umum kerena sebagian pemilih pemula tidak peduli dengan dilaksanakannya pemilihan umum tersebut, selain itu sebagian pemilih pemula menggunakan hak pilih secara dengan baik seperti halnya memilih karena sesuatu alasan tertentu bukan karena memilih untuk mendapatkan pemimpin yang betul-betul bisa memimpin Negara ini dengan baik. Oleh karena itu perlu adanya pemahaman-pemahaman yang baik agar Pemilihan Presiden Wakil Presiden berikutnya pemilih pemula dapat menggunakan hak pilihnya dengan baik.

Berdasarkan uraian latar belakang diatas penulis tertarik melakukan penelitian mengenai perilaku politik pemilih pemula dalam pelaksanaan pemilihan Presiden dana Wakil Presiden 2014 di Desa Kanaungan Kecamatan Labakkang Kabupaten Pangkep dan faktorfaktor yang mempengaruhi perilaku politik pemilih pemula. Bertujuan untuk mengetahui perilaku politik pemilih pemula dalam pelaksanaan pemilihan Presiden dan Wakil Presiden di Desa Kanaungan Kecamatan Labakkang Kabupaten Pangkep dan untuk mengetahui faktor-faktor yang mempengaruhi perilaku politik pemilih pemula dalam pelaksanaan pemilihan Presiden dan Wakil Presiden.

\section{B. KONSEP PERILAKU POLITIK}

Di tengah masyarakat, individu berperilaku dan berinteraksi. Sebagian dari perilaku dan interaksi dapat dicermati akan berupa perilaku politik. Sebagian lainnya berupa perilaku ekonomi, keluarga, agama, dan budaya. Termasuk kedalam kategori kegiatan ekonomi, yakni kegiatan yang menghasilkan barang dan jasa, menjual dan membeli barang dan jasa, mengkonsumsi barang dan jasa, menukar, menanam dan menspekulasikan modal. Namun, hendaklah diketahui pula tidak semua individu ataupun kelompok masyarakat mengerjakan kegiatan politik (Ramlan Subakti, 2010:20).

Ada pihak yang memerintah, ada pula yang menaati pemerintah yang satu mempengaruhi yang lain menentang, dan hasilnya berkompromi; yang satu menjanjikan, yang lain kecewa karena janji tidak dipenuhi; berunding dan tawarmenawar ; yang satu memaksakan putusan berhadapan dengan pihak lain yang mewakili kepentingan rakyat yang berusaha membebaskan; yang satu menutupi kenyataan yang sebenarnya (yang merugikan masyarakat atau yang akan mempermalukan), pihak lain berupaya memaparkan kenyataan yang sesungguhnya, dan mengajukan tuntutan, memperjuangkan mencemaskan apa yang akan terjadi. 
Kegiatan politik yang selalu dilakukan oleh pemerintah (lembaga dan perananya) dan partai politik karena fungsi mereka dalam bidang politik. Oleh karena itu, perilaku politik di bagi dua, yakni perilaku politik lembaga-lemabaga dan para pejabat pemerintah dan perilaku poltik warga Negara biasa (baik individu maupun kelompok). Yang pertama bertanggung jawab membuat, melaksanakan, dan menegakkan keputusan politik, sedangkan yang kedua tidak berwenang seperti yang pertama dalam menjalankan fungsinya karena apa yang dilakukan oleh pihak pertama menyangkut kehidupan pihak kedua. Kegiatan politik pihak kedua ini disebut partisipasi politik.

Suatu keluarga sebagai kelompok juga melaksanakan berbagi kegiatan dalam berbagai bidang, dan karena itu pula mengerjakan kegiatan-kegiatan, seperti ekonomi, pendidikan, agama, rekreasi, dan politik, misalnya demikian. Perilaku keluarga yang berusaha mendapatkan penghasilan untuk biaya hidup, merupakan perilaku ekonomi. Perilaku mereka dalam berolahraga ataupun nonton film adalah perilaku rekreasi; upaya mengajari anak tentang cara hidup yang baik dan mendorong upaya anak belajar di sekolah merupakan perilaku pendidikan; kegiatan warga masyarakat beribadah berupa sembahyang dan berdoa maupun berpuasa, bersedekah dan membantu orang lain untuk berdiri sendiri merupakan perilaku agama.

Para anggota keluarga yang sudah berhak memilih ikut serta dalam proses pemilihan umum, umpamanya aktif dalam kampanye, memberikan iuran, atau dana bagi partai politik, lalu ikut memilih. Selain itu, mereka yang menulis surat yang berkaitan dengan kebijakan pemerintah pada wakil rakyat atau pada pejabat pemerintah, sesungguhnya tengah melakukan kegiatan politik dari berbagai perilaku ini, yang akan menjadi perhatian ilmuwan politik ialah perilaku yang beraspek politik.

Suatu tindakan konkret dapat saja mengandung unsur perilaku politik dan sekaligus ekonomi. Misalnya, keputusan pemerintah untuk mengalokasikan barang dan jasa dalam bentuk pemberian subsidi pertanian, kredit, pengurangan pajak, dan penyuluhan. Demikian pula dengan usaha suatu perusahaan besar untuk mempengaruhi kebijakan perpajakan yang akan diputuskan oleh pemerintah dan Dewan Perwakilan Rakyat (DPR). Dalam hal ini, yang diperhatikan bukan perihal kredit dan perpajakan, melainkan tindakan pemerintah dan kelompok yang diuntungkan (dalam kasus pertama) dan tindakan perusahaan besar yang mempengaruhi pemerintah dan DPR (dalam kasus kedua).

Proses politik akan melahirkan bentuk-bentuk partisipasi politik yang dilakukan oleh individu dan kelompok yang kemudian akan disosialisasikan melalui transmisi kebudayaan, baik melalui pendidikan keluarga, kelompok-kelompok pergaulan, di lingkungan pekerjaan, interaksi melalui model media komunikasi massa, maupun interaksi politik secara langsung. Sehingga kemudian dapat memilahkan kategori budaya politik tersebut atas tiga pemilahan, yaitu budaya politik partisipan, budaya politik subyek dan budaya politik parokialik.

Perilaku politik adalah perilaku yang berkaitan dengan proses politik. Yaitu interaksi antara pemerintah dan masyarakat dalam rangka proses pembuatan, pelaksanaan dan penegakan keputusan politik. Perilaku politik dibagi dua menjadi perilaku politik lembagalembaga dan para pejabat pemerintah yang bertanggung jawab membuat, melaksanakan dan menegakkan keputusan politik dan perilaku politik warga Negara biasa yang tidak berwenang tetapi dapat memengaruhi pihak pembuat keputusan politik (partisipasi politik). 
Surbakti (2010:186) mengelompokan perilaku pemilih menjadi lima pendekatan yaitu :

\section{a. Pendekatan Struktural}

Pendekatan ini menekankan bahwa kegiatan memilih terjadi dalam konteks yang lebih luas seperti struktur sosial, sistem partai, peraturan pemilu dan sebagainya.

b. Pendekatan Sosiologis

Pendekatan ini cenderung menempatkan kegiatan memilih dalam kaitan dengan konteks sosial. Konkretnya, pilihan seseorang dalam pemilu dilatarbelakangi oleh demografi dan sosial ekonomi seperti jenis kelamin, tempat tinggal, pekerjaan, pendidikan, kelas, pendapatan dan agama.

c. Pendekatan Ekologis

Pendekatan ini hanya relevan apabila dalam suatu daerah pemilihan terdapat karakteristik pemilih berdasarkan unit teritorial seperti Desa, Kelurahan, Kecamatan, dan Kabupaten. Pendekatan ekologis ini penting sekali digunakan karena karakteristik data tingkat provinsi pasti berbeda dengan karakteristik tingkat Kabupaten.

d. Pendekatan psikologis

Pendekatan ini melihat faktor psikologis yang melatarbelakangi pilihan seseorang. Konsep yang ditawarkan adalah identifikasi partai. Konsep ini mengacu pada proses pemilihan melalui nama seseorang yang merasa dekat dengan salah satu partai. Identifikasi partai diartikan sebagai perasaan yang sangat dekat yang dimiliki oleh seseorang terhadap salah satu partai.

\section{e. Pendekatan Rasional}

Pendekatan pilihan rasional diartikan sebagai pendekatan memilih sebagai produksi kalkulasi untung dan rugi. Bagi pemilih pertimbangan untung dan rugi digunakan untuk membuat keputusan tentang partai atau kandidat yang dipilih terutama untuk membuat keputusan apakah ikut memilih atau tidak memilih.
Adapun faktor-faktor

yang mempengaruhi perilaku politik Menurut (Ramlan Surbakti 2010:169) yaitu: (1) Lingkungan Sosial politik tak langsung, seperti sistem politik, sistem ekonomi, sistem budaya dan media massa; Lingkungan sosial politik langsung yang mempengaruhi dan membentuk kepribadian aktor, seperti keluarga, agama, sekolah, dan kelompok pergaulan. Dari lingkungan sosial politik langsung seorang aktor mengalami sosialisasi dan internalisasi nilai dan norma masyarakat, termasuk nilai dan norma kehidupan bernegara dan pengalaman-pengalaman hidup pada umumnya lingkungan langsung ini dipengaruhi oleh lingkungan tak langsung; (3) Struktur kepribadian yang tercermin dalam sikap individu. Untuk memahami struktur kepribadan, perlu dicatat bahwa terdapat tiga basis fungsional nilai, yaitu kepentingan, penyesuaian diri, eksternalisai, dan pertahanan diri. Basis yang pertama merupakan sikap yang menjadi fungsi kepentingan. Artinya, penilaian seseorang terhadap suatu objek ditentukan oleh minat dan kebutuhan atas objek tersebut. Basis yang kedua merupakan sikap yang menjadi fungsi penyesuaian diri. Artinya, penilaian terhadap suatu objek tersebut. Basis yang ketiga merupakan sikap yang menjadi fungsi eksternalisasi diri dan pertahanan diri. Artinya penilaian seseorang terhadap suatu objek dipengaruhi oleh keinginan untuk mengatasi konflik batin atau tekanan psikis yang mungkin berwujud mekanisme pertahanan diri dan eksternalisasi diri; (4) Faktor lingkungan sosial poltik langsung berupa situasi, yaitu keadaan yang mempengaruhi aktor secara langsung ketika hendak melakukan suatu kegiatan, seperti cuaca, keadaan keluarga, keadaan ruang, kehadiran orang lain, suasana kelompok dan ancaman dengan segala bentuk.

\section{Pemilih Pemula}


Pemilih pemula adalah pemilih yang baru pertama kali akan melakukan penggunaan hak pilihnya. Pemilih pemula terdiri dari masyarakat yang telah memenuhi syarat untuk memilih. Adapun syarat-syarat yang harus dimiliki untuk menjadikan seseorang dapat memilih adalah: (1) Umur sudah 17 tahun; (2) Sudah / pernah kawin; dan (3) Purnawirawan / Sudah tidak lagi menjadi anggota TNI / Kepolisian.

Pengertian pemilih pemula menurut UU No. 10 tahun 2008 dalam Bab IV pasal 19 ayat 1 dan 2 serta pasal 20 menyebutkan bahwa yang dimaksud dengan pemilih pemula adalah warga Indonesia yang pada hari pemilihan atau pemungutan suara adalah Warga Negara Indonesia yang sudah genap berusia 17 tahun dan atau lebih atau sudah/pernah kawin yang mempunyai hak pilih, dan sebelumnya belum termasuk pemilih karena ketentuan Undang-undang Pemilu.

Pemilih pemula mayoritas memiliki rentang usia 17-21 tahun, kecuali karena telah menikah. Dan mayoritas pemilih pemula adalah pelajar (SMA), mahasiswa dan perkerja muda. Pemilih pemula merupakan pemilih yang sangat potensial dalam perolehan suara pada Pemilu. Perilaku pemilih pemula memiliki karakteristik yang biasanya masih labil dan apatis, pengetahuan politiknya kurang, cenderung mengikuti kelompok sepermainan dan mereka baru belajar politik khususnya dalam pemilihan umum. Ruang-ruang tempat di mana mereka belajar politik biasanya tidak jauh dari ruang yang dianggap memberikan rasa kenyamanan dalam diri mereka.

Menurut pasal 1 ayat (22) UU No 10 Tahun 2008, pemilih adalah warga Negara Indonesia yang telah genap berumur 17 ( tujuh belas) tahun atau lebih atau sudah/pernah kawin, kemudian pasal 19 ayat (1 dan 2) UU No 10 Tahun 2008 menerangkan bahwa pemilih yang mempunyai hak memilih adalah warga
Negara Indonesia yang di daftar oleh penyelenggara Pemilu dalam daftar pemilih dan pada hari pemungutan suara telah genap berumur 17 (tujuh belas) tahun atau lebih atau sudah/pernah kawin.

Berdasarkan pengertian di atas dapat di tarik kesimpulan bahwa pemilih pemula adalah warga Negara yang di datftar oleh penyelenggara pemilu dalam daftar pemilih dan baru mengikuti pemilih (memberikan suara) pertama kali sejak pemilu diselenggarakan dengan rentang usia 17-21 tahun.

Pentingnya peranan pemilih pemula karena sebanyak $20 \%$ dari seluruh pemilih adalah pemilih pemula, dengan demikian jumlah pemilih pemula sangatlah besar, sehingga hak warga Negara dalam menggunakan hak pilihnya janganlah sampai tidak berarti akibat dari kesalahankesalahan yang tidak diharapkan, misalnya jangan sampai sudah memiliki hak pilih tidak dapat menggunakan hak pilihnya karena tidak terdaftar atau juga masih banyak kesalahan dalam menggunakan hak pilihnya.

\section{Pemilihan Umum}

Pemilihan umum merupakan persyaratan minimum Negara demokrasi. Suatu sistem demokrasi dapat di katakan sudah berjalan ketika terpenuhi beberapa karateristik, seperti pemilihan umum yang fair dan periodik, pertanggungjawaban Negara di depan rakyat, dan adanya jaminan kebebasan berekspresi dan berorganisasi (Beetham, 1994). Lebih lanjut Diamond (2003) menulis bahwa demokrasi semakin terkait dengan kebebasan individu dan kelompok untuk bersikap dan mengekspresikan diri.

Pemilu merupakan salah satu sarana pelaksanaan kedaulatan rakyat yang berdasarkan pada demokrasi perwakilan. Dengan demikian, pemilu dapat diartikan sebagai mekanisme penyeleksian dan pendelegasian atau penyerahan kedaulatan kepada orang atau partai yang di percayai (Surbakti, 1992:181). Orang atau partai 
yang di percayai, kemudian menguasai pemerintahan sehingga melalui pemilu diharapkan dapat diciptakan pemerintahan yang representatif (representative goverment).

Berdasarkan Undang-undang Nomor 42 Tahun 2008 mengatakan bahwa pemilihan umum secara langsung oleh rakyat merupakan sarana pelaksanaan kedaulatan rakyat guna menghasilkan pemerintahan Negara yang demokratis, pemilihan umum Presiden dan Wakil Presiden diselenggarakan secara demokratis dan beradab melalui partisipasi rakyat seluas-luasnya berdasarkan asas langsung, umum, bebas, rahasia, jujur, dan adil.

Tujuan pemilihan umun adalah menghasilkan wakil-wakil rakyat yang representatif dan selanjutnya menentukan pemerintahan. Dalam UUD 1945 Bab VII B pasal 22 E ayat (2) pemilihan umum diselenggarakan untuk memilih Dewan Perwakilan Rakyat (DPR), Dewan Perwakilan Daerah (DPD), Presiden dan Wakil Presiden serta Dewan Perwakilan Rakyat Daerah (DPRD), kemudian dijabarkan dalam UU RI Nomor 22 Tahun 2007 bahwa pemilihan umum adalah sarana pelaksanaan kedaulatan rakyat sesuai dengan amanat konstitusional yang diselenggarakan secara langsung, umum, bebas, rahasia, jujur dan adil dalam kerangka Negara Kesatuan Republik Indonesia. Melalui pemilu dan hasilnya, masyarakat mengharapkan perubahan yang berarti untuk memperbaiki kehidupan mereka sehari-hari.

Pemilu di Indonesia dilaksananakan dengan partisipasi rakyat berdasarkan asas langsung, umum, bebas, rahasia, jujur, dan adil serta menjamin prinsip keterwakilan akuntabilitas, dan legitimasi. Seperti pada penjelasan dibawah ini yaitu: (1) Asas langsung, berarti rakyat pemilih mempunyai hak untuk secara langsung memberikan suaranya sesuai dengan kehendak hati nuraninya tanpa perantara;
(2) Asas umum, berarti pada dasarnya semua warga Negara yang memenuhi persyaratan minimal dalam usia, yaitu sudah berumur 17 tahun atau telah atau pernah kawin berhak ikut memilih dalam pemilu. Warga Negara yang sudah berumur 21 tahun berhak dipilih. Jadi, pemilihan yang bersifat umum mengandung makna menjamin kesempatan yang berlaku menyeluruh bagi semua warga Negara yang telah memenuhi persyaratan tertentu tanpa diskriminasi (pengecualian) berdasarkan acuan suku, agama, ras, golongan, jenis kelamin, kedaerahan, dan status sosial; (3) Asas bebas, berarti setiap warga Negara yang berhak memilih bebas menentukan pilihannya tanpa tekanan dan paksaan dari siapapun. Didalam melaksanakan haknya, setiap warga Negara dijamin keamanannya. Sehingga dapat memilih sesuai dengan kehendak hati nurani dan kepentingannya; (4) Asas rahasia, berarti dalam memberikan suaranya, pemilih dijamin bahwa pemilihannya tidak akan diketahui oleh pihak manapun dan dengan jalan apapun. Pemilih memberikan suaranya pada surat suara dengan tidak dapat diketahui oleh orang lain kepada siapa suaranya diberikan. Asas rahasia ini tidak berlaku lagi bagi pemilih yang telah keluar dari tempat pemungutan suara dan secara sukarela bersedia mengungkapkan pilihannya kepada pihak manapun; (5) Asas jujur, berarti dalam pemilihan umum, penyelenggaraan atau pelaksanaan pemerintah dan partai politik peserta pemilu, pengawas dan pemantau pemilu, termasuk pemilih, serta semua pihak yang terlibat secara tidak langsung, harus bersikap dan bertindak jujur sesuai dengan peraturan perundangan yang berlaku; (6)Asas adil, berarti dalam penyelenggaraan pemilu, setiap pemilih dan partai politik peserta pemilu mendapat perlakuan yang sama serta bebas dari kecurangan pihak manapun. 
Sejak tahun 2004 pemilihan Presiden dan Wakil Presiden ini melalui proses pemilihan secara langsung oleh rakyat. Adapun peserta pemilu Presiden dan Wakil Presiden adalah calon yang di usulkan secara berpasangan oleh partai politik atau gabugan partai politik yang memperoleh kursi paling sedikit 20\% (dua puluh persen) dari jumlah kursi DPR atau memperoleh 25\% (dua puluh lima persen) dari suara sah nassional dalam pemilu anggota DPR, sebelum pelaksanaan pemilu Presiden dan Wakil Presiden.

\section{METODE PENELITIAN}

Penelitian dilaksanakan 2 bulan mulai 10 januari sampai 10 maret. Adapun lokasi penelitian yaitu di Desa Kanaungan Kecamatan Labakkang Kabupaten Pangkep disertai dasar pertimbangan bahwa perilaku politik pemilih pemula pada pemilhan presiden dan wakil presiden masih rendahanya perilaku politik dalam berpartisipasi menggunakan hak pilihnya. Jenis penelitian adalah jenis penelitian kualitatif dan tipe penelitian yang digunakan adalah deskriptif kualitatif Sumber data primer adalah data yang di peroleh dengan melakukan penelitian langsung perilaku politik pemilih pemula dari informan serta hasil observasi. Sedangkan data sekunder adalah data yang diperoleh media yang sifatnya melengkapi data primer seperti buku-buku, jurnal ilmiah yang erat kaitannya dengan penelitian ini. Informan terdiri dari Kepala Desa 1 orang, ketua KPPS 1 orang, aanggota KPPS 3 orang, dan pemilih pemula 5 orang.

Tehknik pengumpulan data adalah observasi, wawancara, dan dokumentasi. Untuk mendapatkan daya yang sahih melalui observasi peneliti perlu mengadakan pengamatan tidak hanya satu kali pengamatan saja.

\section{HASIL PENELITIAN DAN PEMBAHASAN}

Intreraksi antara pemerintah dan masyarakat di antara lembaga-lembaga pemerintah dan di antara kelompok dan individu dalam masyarakat dalam rangka proses pembuatan, pelaksanaan, dan penegakan keputusan politik, pada dasarnya merupakan perilaku politik.

\section{Perilaku Politik Pemilih Pemula Dalam Pelaksanaan Pemilihan Presiden dan Wakil Presiden 2014 di Desa Kanaungan Kecamatan Labakkang Kabupaten Pangkep.}

Perilaku politik pemilih pemula dalam pelaksanaan pemilihan Presiden dan Wakil Presiden dapat dilihat dari beberapa pendekatan dalam menganalisis kecenderungan pemilih pemula.

1) Pendekatan Struktural

Pendekatan struktural, kita dapat melihat kegiatan pemilih ketika memilih, partai politik sebagai produk dari konteks struktur yang luas seperti struktur sosial masyarakat yang mewakili aspirasi masyarakat, sistem kepartaian, sistem pemilu, dan program yang ditonjolkan partai-partai peserta pemilu. Dalam model ini, tingkah laku politik seseorang termasuk dalam penentuan pilihan ditentukan oleh pengelompokan sosial, agama, bahasa, dan etnis/suku. Dalam pendekatan ini melihat bagaimana perilaku pemilih dalam memilih berdasarkan kelas sosial, agama, bahasa, dan suku atau etnis. Dalam memilih jika kita lihat dari sisi pendekatan ini maka para pemilih akan menentukan pilihannya berdasarkan pertimbangan pada penjelasan sebelumnya dan selalu mempertimbangankan segala sesuatu yang akan merubah pemikiran mereka dalam menentukan pilihan.

Berdasarkan wawancara yang dilakukan kepada salah seorang pemilih pemula dalam pelaksanaan Pemilihan Presiden dan Wakil Presiden, adalah sebagai berikut :

"Ya saya ikut menggunakan hak pilih saya karna saya sadar bahwa saya harus menggunakan hak pilih saya karna satu suara itu sangat penting dalam pemilihan presiden dan wakil presiden ini. Serta 
mengikuti pemilihan presiden ini dengan benar sesuai aturan yang berlaku". (Wawancara KT).

Kesadaran politik yang dimiliki pemilih pemula sebagai warga Negara akan hak dan kewajiban dalam menentukan dan berpartisipasi dalam pemilihan Presiden dan Wakil Presiden. Pemilih pemula beranggapan bahwa dengan memberikan dan menggunakan hak suara yang dimiliki sangatlah berpengaruh karena satu suara sangat penting. Meskipun belum mengetahui sosok manusia yang jadi pemimpin ideal sebab mereka hanya mengenal para calon pemimpin tersebut lewat media.

Peran serta pemilih pemula dalam sangat penting karena keikutsertaan mereka dalam pemilu merupakan suatu dukungan dalam pembangunan Negara kita. Karena dalam pemilu, pemilih pemula dapat menyalurkan suara secara langsung pemimpin yang memiliki karakter sesuai dengan keinginan bersama yakni mempunyai pemimpin yang kharismatis dan bertanggung jawab.

Pemilih pemula masih memiliki kesadaran akan hak dan kewajiban mereka untuk berpartisipasi dalam pelaksanaan pemilihan Presiden dan Wakil Presiden dengan memilih calon pemimpin yang dapat menyejahterakan rakyat. Serta keterlibatan mereka dalam pelaksanaan pemilu untuk menjawab rasa penasaran mereka dalam menggunakan hak pilih yang dimiliki, meskipun belum mengetahui sosok pemimpin yang dipilih apakah tepat atau tidak karena mereka hanya mengenal calon pemimpin melalui media. Hal ini sesuai dengan yang dikemukakkan oleh Surbakti (2010:186) Pendekatan ini menekankan bahwa kegiatan memilih terjadi dalam konteks yang lebih luas seperti struktur sosial, sistem partai, peraturan pemilu dan sebagainya.

2) Pendekatan Sosiologi
Pendekatan ini lebih menekankan kepada faktor-faktor sosiologi yang kemudian membentuk perilaku memilih seseorang. Pendekatan ini pada dasaranya menjelaskan bahwa karakteristik dan pengelompokkan sosial mempunyai pengaruh dalam menentukan perilaku memilih seseorang. Perilaku pemilih tentu dapat dijelaskan akibat pengaruh seseorang terhadap suatu kelompok sosial dan norma-norma yang dianut oleh kelompok atau organisasi. Sosiologi berusaha memahami hakikat masyarakat dalam kehidupan kelompok, baik struktur, dinamika, institusi, dan interaksi sosialnya. Sosiologi dan antropologi saling menunjang dari segi teori maupun konsepnya. Konsentrasi sosiologi pada masyarakatnya, sedangkan konsentrasi antropologi pada kebudayaannya. Antara keduanya jelasjelas tidak bisa dipisahkan, karena masyarakat dalam kelompok manusia dalam kehidupan bermasyarakat.

Perilaku politik pemilih pemula pada Desa Kanungan pada umumnya karena faktor sosiologi, berdasarkan wawancara yang dilakukan oleh salah satu pemilih pemula dalam pelaksanaan pemilih Presiden dan Wakil Presiden, adalah sebagai berikut:

"Saya memberikan suara saya kepada salah satu calon presiden karena orang tua dan semua keluarga saya memberikan suaranya kepada kandidat tersebut jadi secara otomatis saya sebagai anak juga harus mengikuti pilihan orang tua dan keluarga saya" (Wawancara MT).

Komunikasi sehari-hari yang dilakukan orang tua merupakan faktor penting yang mendasari seseorang untuk menggunakan hak politiknya sebagai warga Negara. Selain keputusan untuk memilih, kandidat yang menjadi pilihan seseorang dalam pemilu juga banyak dipengaruhi oleh faktor keluarga/orang tua. Dua pengaruh yang paling besar dalam membentuk 
orientasi politik seseorang adalah politik orang tua dan tekanan sosial di masa orang tersebut berpartisipasi dalam Pemilu.

Pemilih pemula cenderung mengikuti apa yang dipilih orang tuanya karena merasa bahwa orang tuanya lebih berpengalaman dalam hal menentukan pemipin, berbeda dengan mereka yang baru pertama kali memberikan suaranya yang belum memilki pengalaman sama sekali.

Selanjutnya pemilih pemula hanya mengikut kepada orang tua dan keluarga karena mereka tidak mampu melihat karakteristik pemimpin yang akan dipilihnya, mereka menganggap pilihan orang tua adalah pilihan yang terbaik karena sudah memiliki pengalaman dari pemilihan-pemilihan sebelumnya. Hal ini sejalan dengan pandangan Surbakti (2010:186) yang berkaitan dengan pendekatan sosiologi cenderung menempatkan kegiatan memilih dalam kaitan dengan konteks sosial. Konkretnya, pilihan seseorang dalam pemilu dilatarbelakangi oleh demografi dan sosial ekonomi seperti jenis kelamin, tempat tinggal, pekerjaan, pendidikan, kelas, pendapatan dan agama.

3) Pendekatan ekologis

Pendekatan ekologi adalah suatu metodologi untuk mendekati, menelaah, dan menganalisis suatu gejala atau masalah dengan menerapkan konsep dan prinsip ekologi. Dalam hal ini, metodologi pendekatan, penganalisisan, dan penelaahan gejala dan masalah geografi. Pendekatan ini menggunakan wilayah sebagai sasaran utama dalam melihat perilaku pemilih dalam menentukan pilihannya. Manusia dalam hal ini tidak boleh diartikan sebagai makhluk biologis semata yang setara dengan makhluk hidup lainnya, namun adalah sosok yang dikaruniai daya cipta, rasa, karsa, karya atau makhluk yang berbudi daya.

Berdasarkan wawancara yang di lakukan dengan anggota KPPS dalam pelaksanaan pemilihan Presiden dan wakil Presiden, berikut kutipannya :

"Menurut pendapat saya, pemilih pemula belum memahami betul keadaan politik, mereka sekedar ikutserta saja pada pesta demokrasi yang terjadi, tanpa ada pertimbangan, apakah yang dipilihnya tepat atau dapat memipin kita dengan baik, selain itu juga saya melihat mereka itu lebih dominan pada pergaulan mereka sendiri dan masa bodoh dengan pemilihan tersebut, mungkin ini diakibatkan karena mereka malihat tidak kurang sekarang ini caloncalon pemimpin sulit di percaya karena tersangkut kasus". (Wawancara HW).

Pemahaman mengenai politik menjadi kendala dalam pelaksanaan pemilihan Presiden dan Wakil Presiden bagi pemilih pemula. Mereka (Baca: Pemillih pemula) beranggapan penyelanggaraan pemilu ini hanya sebagai budaya yang setiap periode dilaksanakan. Keikutsertaan mereka hanya untuk memenuhi hak dan kewajiban mereka dalam pelaksanaan pemilu sebagai warga Negara, tanpa ada pertimbangan atau melihat karakteristik calon pemimpin yang dipilihnya apakah memang layak atu pantas dipilih.

Melihat beberapa kasus yang dialami oleh beberapa wakil rakyat menjadi alasan bagi pemilih pemula kurang berpartisipasi dan bersikap acuh terhadap penyelenggaraan pemilu. Mereka tidak peduli siapa yang akan terpilih.

Keikutsertaan pemilih pemula dalam pelaksanaan pemilihan Presiden dan Wakil Presiden hanya untuk menjalankan hak dan kewajiban mereka sebagai warga Negara dengan melihat antusisas masyarakat setiap pesta demokrasi dilaksanakan tanpa melihat karakteristik calon pemimpin yang dipilihnya.

4) Pendekatan psikologis 
Pendekatan psikologi sosial menjelaskan bahwa tingkah laku pemilih akan sangat dipengaruhi oleh interaksi antara faktor internal dan ekternal individu dalam bermasyarakat. Pendekatan Psikologi sosial juga bisa menjelaskan bagaimana sikap dan harapan masyarakat dapat melahirkan tindakan serta tingkah laku yang berpegangan teguh pada tuntutan sosial.

Pada pendekatan psikologi, pemilih pemula lebih cenderung menjatuhkan pilihannya karena adanya konteks ketokohan yang dominan. Berdasarkan wawancara yang dilakukan kepada salah seorang pemilih pemula dalam pelaksanaan pemilihan Presiden dan Wakil Presiden, adalah sebagai berikut :

"Saya menjatuhkan pilihan saya kepada kandidat yang saya pilih karena saya sangat mengidolakan beliau, dan saya yakin bahwa beliau bisa memipin Negara ini dengan baik. Melihat pengalamanpengalaman beliau sebelumnya bisa memipin Negara ini dengan baik". (Wawancara MW).

\section{Kekaguman terhadap kandidat menjadi alasan pemilih pemula menjatuhkan pilihannya, mereka meresa sudah sangat mengenal sosok calon pemimpin yang dipilihnya baik itu latar belakang maupun pengalaman politik sebelumnya.}

Dalam penetapan pilihan mereka (Baca: Pemilih pemula) memberikan suaranya kepada sang kandidat karena mereka mengidolakan kandidat tersebut sehingga sehingga mereka lebih mudah percaya dalam memimpin, dengan melihat pengalamannya dan adanya ikatan emosional yang ada pada dirinya karena sifat merakyat yang menurutnya pantas menjadi seorang pemimpin. Hal ini sesuai yang dikemukakan oleh Surbakti (2010:186) Pendekatan ini melihat faktor psikologis yang melatarbelakangi pilihan seseorang. Konsep yang ditawarkan adalah identifikasi partai. Konsep ini mengacu pada proses pemilihan melalui nama seseorang yang merasa dekat dengan salah satu partai. Identifikasi partai diartikan sebagai perasaan yang sangat dekat yang dimiliki oleh seseorang terhadap salah satu partai.

5) Pendekatan rasional

Pendekatan pilihan rasional melihat kegiatan memilih sebagai produk kalkulasi untung dan rugi. Yang dipertimbangkan tidak hanya "ongkos" memilih dan kemungkinan suaranya dapat memengaruhi hasil yang diharapkan, tetapi ini digunakan pemilih dan kandidat yang hendak mencalonkan diri untuk terpilih sebagai wakil rakyat atau pejabat pemerintah. Bagi pemilih, pertimbangan untung dan rugi digunakan untuk membuat keputusan tentang partai atau kandidat yang dipilih, terutama untuk membuat keputusan apakah ikut memilih atau tidak ikut memilih.

Berdasarkan wawancara yang dilakukan kepada salah seorang pemilih pemula dalam pelaksanaan pemilihan Presiden dan Wakil Presiden, adalah sebagai berikut:

"Saya melihat beberapa program yang dijanjikan sangat bagus, oleh karena itu saya yakin bahwa beberapa program yang akan dijalankan bisa menyejahterakan rakyat" (Wawancara ST).

Program-program yang dijanjikan menjadi salah satu alasan dalam menentukan pilihan, dengan melihat program yang di janjikan tentu hal ini membuat mereka yakin dalam memilih calon pemimpin tersebut. Karena dengan terlaksananya program tersebut secara otomatis akan lebih mensejahterakan masyarakat, namun kemungkinan tidak berjalannya program yang telah dijanjikan masih belum jelas, ini merupakan alasan yang rasional dalam memilih calon pemimpin. 
Dalam hal ini pemilih pemula sudah dapat memilih secara rasional dalam menggunakan hak pilih yang diberikan dengan beberapa pertimbangan dengan melihat program-program yang dijanjikan bahkan melihat dari pengalamanpengalaman dalam berpolitik yang dilakukan sebelumnya. Hal ini sesuai dengan yang diungkapkan oleh Surbakti (2010:186) Pendekatan pilihan rasional diartikan sebagai pendekatan memilih sebagai produksi kalkulasi untung dan rugi. Bagi pemilih pertimbangan untung dan rugi digunakan untuk membuat keputusan tentang partai atau kandidat yang dipilih terutama untuk membuat keputusan apakah ikut memilih atau tidak memilih.

\section{Faktor-faktor Yang Mempengaruhi Perilaku Politik Pemilih Pemula Dalam Pelaksanaan Pemilihan Presiden dan Wakil Presiden 2014.}

Perilaku politik terbentuk akibat adanya interaksi sosial yang di lakukan oleh pemerintah dengan masyarakat, interaksi sosial bukan berarti ada kontrak politik dengan pemerintah.

a) Faktor Pendukung

Adapun yang menjadi faktor pendukung bagi pemilih pemula dalam mengikuti proses pemilihan Presiden dan wakil Presiden tahun 2014 yakni:

(1) Lingkungan Sosial;

Kehidupan politik dari pendekatan sistem bisa dilihat dari berbagai sudut, misalnya dengan menekankan pada kelembagaan yang ada, kita bisa melihat pada struktur hubungannya antara berbagai lembaga atau institusi pembentuk sistem politik. Hubungan antara berbagai lembaga Negara sebagai pusat kekuatan politik misalnya, merupakan satu aspek, sedangkan peranan partai politik dan kelompok-kelompok penekan merupakan bagian lain dari suatu sistem politik. Dengan merubah sudut pandang maka sistem politik bisa dilihat sebagai kebudayaan politik, lembaga-lembaga politik, dan perilaku politik.
Berdasarkan wawancara yang dilakukan kepada Kepala Desa, mengenai faktor yang mendukung perilaku politik pemilih pemula adalah sebagai berikut:

"Menurut saya, dari beberapa pemilih pemula, pemilih pemula yang ikutserta dalam pemilihan Presiden dan Wakil Presiden dikarenakan mereka penasaran akan keadaan politik yang terjadi sekarang ini, dengan melihat beberapa hal yang terjadi saat ini melalui beberapa media". (Wawancara HS).

Pengalaman yang sangat minim dalam pesta demokrasi yang mulai berkembang di Negeri ini menjadikan kelompok pemilih pemula ingin ikut andil dalam pesta demokrasi dan ingin merasakan secara langsung keterlibatan mereka dalam kegiatan pemilu.

Keiikutsertaan dalam pemilihan Presiden dan Wakil Presiden bukan hanya karena hal ini adalah pengalaman pertama bagi mereka (Baca: Pemilih Pemula), melainkan mereka memandang pemilihan ini hanya budaya yang setiap periode dilaksanakan yakni setiap 5 tahun. Hal ini sesuai dengan yang dikemukakan oleh Surbakti (2010:169) Lingkungan sosial politik tak langsung, seperti sistem politik, sistem ekonomi, sistem budaya dan media massa.

(2) Struktur Kepribadian

Pada struktur kepribadian pemilih pemula menilai aktor-aktor politik diantara mereka masih ada yang dapat dipercaya meskipun sebagian besar dari mereka terlibat dari beberapa kasus, sebab hal ini tergantung dari pemilih apakah mereka memilih pamimpin yang benar-benar memiliki karakter dan pengalaman politik yang baik atau memilih karena beberapa alasan-alasan tertentu yang tidak rasional. Wawancara diungkapkan oleh salah seorang pemilih pemula adalah sebagai berikut: 
"Saya sudah lama ingin ikut memilih, saya ingin merasakan bagaiaman rasanya ikut berpartisipasi dalam memilih calon pemimipin, dan disaat sudah mempunyai kesempatan untuk memilih maka saya mempergunakan kesempatan itu dengan baik dan berharap pilihan saya itu tepat". (Wawancara MT).

Melihat masyarakat yang memiliki hak pilih dalam berpartisipasi menjadikan pemilih pemula termotivasi dalam menggunakan hak pilih yang dimiliki, rasa keingintahuan mereka dalam memberikan hak suara yang dimiliki menjadi faktor pendukung. Kesempatan yang pertama kali dimiliki dalam pesta demokrasi tentu digunakan dengan baik melalui penilaianpenilain mereka terhadap beberapa kandidat tersebut.

Hal ini menjadikan pemilih pemula memiliki rasa ingin tahu yang besar akan pelaksanaan pesta demokrasi yang diadakan dengan memilih calon pemimpin melalui penilaian yang dimiliki. Hal ini sesuai yang dikemukakan oleh Surbakti (2010:169) Struktur kepribadian yang tercermin dalam sikap individu. Untuk memahami struktur kepribadan, perlu dicatat bahwa terdapat tiga basis fungsional nilai, yaitu kepentingan, penyesuaian diri, eksternalisai, dan pertahanan diri. Basis yang pertama merupakan sikap yang menjadi fungsi kepentingan. Artinya, penilaian seseorang terhadap suatu objek ditentukan oleh minat dan kebutuhan atas objek tersebut. Basis yang kedua merupakan sikap yang menjadi fungsi penyesuaian diri. Artinya, penilaian terhadap suatu objek tersebut. Basis yang ketiga merupakan sikap yang menjadi fungsi eksternalisai diri dan pertahanan diri.artinya penilaian seseorag terhadap suatu objek dipengaruhi oleh keinginan untuk mengatasi konflik batin atau tekanan psikis yang mungkin berwujud mekanisme pertahanan diri dan eksternalisasi diri.

b) Faktor Penghambat

Berbeda dengan faktor pendukung, faktor ini hadir untuk melihat sisi lain dari perilaku pemilih pemula dalam menanggapi pemilihan Presiden dan wakil presiden secara pesimis. Hingga melahirkan apatisme terhadap pesta demokrasi tersebut (Baca: Pemilu). Adapun yang menjadi penghambat bagi pemilih pemula dalam menggunakan hak pilihnya yakni:

(1) Kepribadian Aktor

Kepribadian seseorang itu bukan ditentukan oleh faktor bawaan lahir. Melainkan hasil proses belajar, baik itu proses belajar tanpa sadar sebagai reaksi penyesuaian terhadap lingkungan maupun hasil belajar yang disengaja atau direncanakan dari berbagai pengalaman. Wujud kepribadian itu dapat dilihat melalui kualitas perilaku secara keseluruhan. Sikap yang dimiliki pemilih pemula terhadap partisipasi yang diberikan tergantung dari lingkungan sekitar. Berdasarkan hasil wawancara dengan anggota KPPS, mengenai hambatan pemilih pemula dalam perilaku politik adalah sebagai berikut:

"Menurut saya, terkait dengan faktor penghambat perilaku politik disebabkan karena sebagian para pemilih pemula masih lebih memikirkan dan menikmati pergaulan mereka sendiri dibandingkan mengetahui keadaan politik yang terjadi saat ini". (Wawancara SW).

Ketidaktahuan mereka akan pemahaman politik dan pengaruh dari pergaulan yang terjadi pada mereka menunjukan ketidakpedulian mereka terhadap calon pemimpin yang terdaftar, serta ketidakpercayaan mereka akan pemimpin yang terpilih juga menjadi salah satu faktor yang mempengaruhi hal tersebut. 
Sesuai dengan pendapat Surbakti (2010:169) bahwa Lingkungan sosial politik langsung yang mempengaruhi dan membentuk kepribadian aktor, seperti keluarga, agama, sekolah, dan kelompok pergaulan. Dari lingkungan sosial politik langsung seorang aktor mengalami sosialisasi dan internalisasi nilai dan norma masyarakat, termasuk nilai dan norma kehidupan bernegara dan pengalamanpengalaman hidup pada umumnya lingkungan langsung ini dipengaruhi oleh lingkungan tak langsung.

(2) Kurangnya sosialisasi

Situasi politik yang terjadi sekarang ini menjadi tolak ukur pemilih pemula bahwa meskipun pemilihan umum ini dilaksanakan setiap periode namun tidak sedikit pemimpin atau wakil rakyat yang terpilih menyalahgunakan kekuasaan yang dimilikinya. Berdasarkan wawancara yang dilakukan kepada anggota KPPS, adalah sebagai berikut:

"Menurut pendapat saya, terkait dengan perilaku politik pemilih pemula bahwa salah satu penyebab rendahnya perilaku politik pemilih pemula dalam dunia politik dikarenakan kurangnya kesadaran dalam berpartisipasi, selain itu pemilih pemula juga kurang percaya dengan para calon pemimpin melihat sekarang ini tidak sedikit pemimpin kita, menyelewengkan wewenang yang telah di percayakan oleh masyarakat. Sehingga untuk ingin melakukan peran dalam pemilu masih ada keraguan untuk ikut berpartisipasi dalam arena politik yang terjadi. Oleh karena itu perlu di lakukan sosialisasi bagi para pemilih pemula, serta harus memiliki kesadaran politik". (Wawancara HR).

Rendahnya perilaku politik bagi pemilih pemula disebabkan kurangnya pemahaman politik serta proses penyampaian informasi mengenai politik yang berfungsi sebagai komunikator politik yang menyampaikan segala keputusan dan penjelasan pemerintah kepada masyarakat juga menyampaikan aspirasi dan kepentingan berbagai kelompok masyarakat kepada pemerintah.

Kepercayaan masyarakat kepada partai politik mulai menurun dengan melihat politisi-politisi yang lebih mementingkan kepentingannya sendiri dibandingkan kepentingan rakyat apabila sudah terpilih menjadi wakil rakyat atau pemimpin, bahkan tidak sedikit dari beberapa politisi yang sudah diberikan tanggung jawab menyelewengkan kekuasaan yang telah diberikan.

Sosialisasi dalam pemilu perlu dilakukan agar pemilih memahami akan pentingnya berpartisipasi dalam pelaksanaan pemilihan umum sebab suara yang dimilki sangat berharga untuk masa depan suatu Negara.

Rendahnya partisipaasi politik pemilih pemula di Desa Kanaungan disebabkan oleh kurangnya pemahaman politik serta kurangnya kepercayaan pemilih kepada calon pemimpin dengan melihat situasi saat ini bahwa sebagian politisi-politisi yang sudah terpilih terlibat berbagai kasus misalnya kasus korupsi hingga berkaitan dengan etika. Hal ini yang menghambat partisipasi masyarakat khususnya bagi pemilih pemula yang ada di Desa karena menurut mereka siapapun yang terpilih tidak akan merubah kondisi sekarang ini. Hal ini sejalan dengan teori Surbakti (2010:169).

\section{E. KESIMPULAN}

Berdasarkan hasil penelitian maka dapat diperoleh kesimpulan bahwa perilaku politik pemilih pemula dalam pelaksanaan pemilihan presiden dan wakil presiden 2014 di Desa Kanaungan Kecamatan Labakkang Kabupaten Pangkep yang bertujuan untuk meningkatkan perilaku politik pemilih pemula untuk berpartisipasi dalam pelaksanaan 
pemilihan presiden dan wakil presiden 2014 di Desa Kanaungan Kecamatan Labakkang Kabupaten Pangkep. Perilaku politik pemilih pemula dalam pelaksanaan pemilihan presiden dan wakil presiden di Desa Kanaungan Kecamatan Labkkang Kabupaten Pangkep kurang maksimal. Hal ini dapat dilihat dari beberapa pendekatan yang terjadi pada pemilih pemula yaitu: (a) Pendekatan struktural yang terjadi pada pemilih pemula yaitu pemilih pemulai memiliki kesadaran untuk menggunakan hak pilihnya dalam pemilihan Presiden dan Wakil Presiden dengan mengikuti peraturan-peraturan pemilu.

pendekatan sosiologi, pemilih pemula memberikan suaranya kepada salah seorang kandidat yang terdaftar karena pengaruh dari orang tua dan keluarga. (c) pendekatan ekologi, pemilih pemula masih mengikuti lingkungan sekitarnya yakni mereka lebih memilih untuk melaksanakan kegiatan mereka dibandingkan harus ikut serta dalam pemilu. (d) pendekatan psikologi, pemilih pemula memberikan karakteristik calon pemimpin yang dipilihnya. Dan (e) pendekatan rasional, pemilih pemula menjatuhkan pilihannya dengan melihat program-program yang dijanjikan. Dari beberapa pendekatan yang terjadi para pemilih pemula masih menggunakan emosional mereka tanpa mengetahui betul apakah pilihan mereka layak untuk dipilih atau tidak dengan melihat pengalaman mereka sebelumnya.

Faktor-faktor yang mempengaruhi perilaku politik pemilih pemula dalam pelaksanaan pemilihan presiden dan wakil presiden 2014 di Desa Kanungan Kecamatan Labakkang Kabupaten Pangkep yaitu faktor pendukung yaitu Lingkungan Sosial. Pemilih pemula mengikuti pemilhan presiden dan wakil presiden melihat kebiasaan dan budaya setiap pesta demokrasi tiba. Struktur Kepribadian. Rasa ingin tahu yang ada peda pemilih pemula untuk berpartisipasi dalam pelaksanaan pemilihan presiden dan wakil presiden
2014. Sedangkan faktor penghambat yaitu Kepribadian Aktor. Pemilih pemula lebih memikirkan pergaulan mereka dibanding mencari tahu keadaan politik yang terjadi sekarang ini. selain itu ketidakpercayaan pemilih pemula terhadap calon pemimpin yang akan datang dengan melihat beberapa kasus yang terjadi pada para wakil rakyat tersebut.

Adapun saran-saran berdasarkan hasil pengamatan penulis yakni: pertama, perlunya pendidikan politik untuk para pemilih pemula agar dapat memilih dengan baik. Kedua, perlunya kesadaran politik pemilih pemula untuk berpartisipasi dalam pelaksanaan pemilihan presiden dan wakil presiden 2014 di Desa Kanungan Kecamatan Labakkang Kabupaten Pangkep. Ketiga, Perlunya sosialisasi tentang pentingnya berpartisipasi dalam pemilihan umum.

\section{DAFTAR PUSTAKA}

Antonius, Sitepu, P. 2012. Teori-Teori Politik. Yogyakarta: Edisi Pertama Graha Ilmu.

Budiardjo,Miriam.2008. Dasar-Dasar Ilmu Politik. Jakarta: PT Gramedia Pustaka Utama.

Damsar. 2010. Pengantar Sosiologi Politik. Jakarta: Kencana Prenada Media Group.

Gatara, Sahid, A, A. 2008. Ilmu Politik (Memahami dan Menerapkan). Bandung: Pustaka Setia.

Melani, Indar. 2014. Perilaku Pemilih Pemula Di Kecamatan Duampanua Pada Pemilukada Kabupaten Pinrang Tahun 2013.

http://repository.unhas.ac.id/.../SKRI PSI\%20INDAR\%20MELANI.pdf?...1

(diakses tanggal 15 Februari 2015)

Norris. 2006. Pemilihan Umum dan

Perilaku Memilih. Bandung: Remaja

Rosdakarya.

Ramadhan, Hermawan. 2012. Perilaku Pemilih Di Kelurahan Penyengat Pada Pemilihan Umum Kepala Daerah Kota 
Tanjung Pinang Tahun 2012.

http//jurnal.umrah.ac.id/?p=2974

(diakses tanggal 22 Februari2015)

Rubyanti, Rika. 2009. Pengaruh Popularitas

Terhadap Pilihan Pemilih Pemula.

http//repository.usu.ac.id/bitstream/

123456789/1/09E011224.pdf (di

akses tanggal 10 Februari 2015).

Sugiono. 2005. Faktor Yang Mempengaruhi

Pemilih Dalam Pemilihan Kepala

Daerah Langsung: Persfektif Political

Marketing. Jakarta: Majalah Usahawan

No.5,Th 2004, Mei 2005.

Sugiyono. 2014. Metode Penelitian

Kuantitatif Kualitatif dan $R$ dan $D$.

Bandung: Alfabeta.

Surbakti, Ramlan. 2010. Memahami Ilmu

Politik. Jakarta: PT Gramedia

Widiasarana Indonesia.

Dokumen :

Undang-Undang No. 10 Tahun 2008

Tentang Pemilihan Anggota Dewan

Perwakilan Rakyat, Dewan

Perwakilan Daerah, Dan Dewan

Perwakilan Daerah.

Undang-Undang No. 42 Tahun 2008

Tentang Pemilihan Presiden dan

Wakil Presiden. 